\title{
SOCIOKULTURNA ANIMACIJA DRUŽBI VDIHNE ŽIVLJENJE - O POVEZOVANJU DRUŽBENEGA IN KULTURNEGA SREDI NOVE KULTURE
}

Dr. Dušana

Findeisen

Filozofska fakulteta

Univerze $v$ Ljubljani

\section{POVZETEK}

Avtorica uvodoma razpravlja o nekdanjih oblikah prenašanja znanja in kulture na prebivalce, oblikah, kakršne poznamo predvsem v času nastajanja nacionalnih držav: narodno buditeljstvo in izobraževanje odraslih. Ob tem poudari, da je imela sleherna nacionalna država svoje narodne buditelje, ki so z navduševanjem, povezovanjem, kulturnim izobraževanjem prebivalcev družbi vdihnili dinamično življenje. Sociokulturna animacija je francoski koncept, ki kljub imenu ni sodoben pojav, saj izvira iz ljudskega izobraževanja, po drugi svetovni vojni pa se pridevnik ljudsko začne opuščati in vse bolj je v rabi izraz sociokulturna animacija. Sociokulturno animacijo je najti povsod tam, kjer so ljudje, naj bodo različnega stanu in iz različnih slojev ali družbenih skupin, njen cilj pa je izboljševati človeka in človeštvo. Avtorica naniza raznolike opredelitve sociokulturne animacije in jih ponekod ilustrira $z$ daljšimi prikazi primerov. Navede tudi prevladujoče kriterije za klasifikacijo oblik sociokulturne animacije, možne nosilce in nazadnje tudi funkcije sociokulturne animacije. Podčrta, da je sociokulturna animacija podsistem francoske kulturne politike, kar jo naredi različno od drugih oblik izobraževanja odraslih za življenje.

Ključne besede: sociokulturna animacija, sociokulturni animator, izobraževanje odraslih, ljudsko izobraževanje, prosti čas, kulturna politika

$\mathrm{N}$ bujanja (angl. promotion), izobraževanja v skupnosti (angl. community education), narodnega prebujanja, skupnostnega razvoja (angl. community development). Danci verjamejo, da se je skupnostno izobraževanje razvilo pri njih z ljudskimi visokimi šolami, Švedi, da so študijski krožki, ki so nastali na začetku 20. stoletja, oblika skupnostnega izobraževanja, Francozi, da se vse začenja sredi francoske revolucije z delavskimi krožki. Če noben narod ne more natanko opredeliti začetka tega prebivalcem namenjenega, organiziranega in na kulturi temelječega izobraževanja za življenje, pa mnogi prepoznajo svoje prosvetljene buditelje oziroma, z današnjim izrazom rečeno, sociokulturne animatorje. Sociokulturna animacija, kamor ti sodijo, je francoski koncept, ki se po drugi svetovni vojni udejanji in da podlago podsistemu francoske kulturne politike. To dejstvo vpliva na načrtni razvoj sociokulturne animacije in na demokratizacijo kulture, kajti 
država kot najširši okvir solidarnosti solidarnostno poskrbi za nastanek kulturnih domov vseh vrst in podpre dejavnosti različnih nosilcev od posameznikov prek skupin, društev, podjetij, ustanov do ministrstev.

\section{NARODNI BUDITELJI IN IZOBRAŽEVANJE ODRASLIH}

Avstrijci denimo omenjajo Georga Wieningerja (1850-1925), začetnika izobraževanja odraslih na podeželju, ki je v Schärdingu ustanovil središče za izobraževanje odraslih na podeželju, tam pa uporabil vse znanje, ki ga je prej preizkušal na posestvu svojega očeta. Za buditelje je bilo značilno, da so potovali, opazovali, hodili okrog z odprtimi očmi. Tako je tudi Wieninger zbiral znanje s področja znanosti, tehnologije in kmetovanja. Leta 1809 je ustanovil »kolegij za kmete« (nem. Bauernhochschule). Do leta 1911 je tam predaval vsaj 600-krat ter obravnaval poklicne in splošne izobraževalne vsebine za široko javnost in kmete. Posebno pozornost je namenil izobraževanju učiteljev (FriedelSieglhuber, v Marta Friedenthal Haasse (ur.), 1998: 559). Avstrijci so prepričani, da je Georg Wieninger predhodnik izobraževalnih ustanov za odrasle, pa tudi začetnik političnega aktiviranja podeželskega prebivalstva.

Nemci omenjajo Fredo Wuesthoff (18961956), doktorico fizike, matematike in kemije, specializirano za področje patentov, ki je ob svojem poklicnem delu spletla številne mednarodne stike. V južni Nemčiji je po drugi svetovni vojni začela $\mathrm{z}$ izobraževanjem odraslih za mir. Skupaj z nekaj ženskami je leta 1946 po napadu $\mathrm{z}$ atomsko bombo osnovala krožke za mir (Friedenskreise). Ta skupina buditeljic je hotela prebivalstvo poučiti o nevarnostih atomske bombe za človeštvo. Ženske so vodile številna predavanja o tej temi. Prvo konferenco žensk o ženskah in miru pa je Freda Wuesthoff v Frankfurtu organizirala že leta 1940 (Ziegler, C., v Marta Friedenthal Haasse (ur.), 1998: 642-643).
Na Slovaškem je deloval Juraj Fandly (17501811), ki je bil vikar v karpatskih vaseh. Razširjal je med ljudi ideje razsvetljenstva in organiziral izobraževalne dejavnosti (Čornaničova, R., v Marta Friedenthal Haasse (ur.), 1998: 727-739). Leta 1792 je skupina mladih duhovnikov želela na prebivalce poleg religioznih prenesti tudi izobraževalne in kulturne vsebine. Nastalo je Slovaško združenje razumnikov v Trnavi, ki je pripravila tudi podlage za slovaški knjižni jezik (prav tam).

Na Slovenskem pa je deloval Janez Evangelist Krek, katoliški duhovnik, ki ga je cerkev zaradi drugačnosti in nepodrejanja njenim doktrinam zavračala. Krek je predaval, ustanavljal številna društva, hranilnice, se bojeval za matere samohranilke, delavce in vse, ki jih je družba potiskala na rob. Deloval je tudi politično, kot poslanec $\mathrm{v}$ dunajskem parlamentu. Napisal je več člankov in knjigo Socializem (Juhant, 1989).

Ali nemara Matija Vertovec, bogoslovec, duhovnik, ki je spodbujal vaščane, jih izobraževal, da bi se njegova vas izognila kugi. Skupaj $\mathrm{z}$ mlajšim bratom je hodil po svetu in domov prinašal znanje. $\mathrm{V}$ svojem in farnem vinogradu in kleti je denimo preizkušal trsne in sadne trte, pridelovalne postopke in kletarska opravila, novosti poskušal znanstveno raztolmačiti tudi na podlagi tujih izsledkov. Prepričeval in spodbujal je vinogradnike, jih izobraževal, da bi mu sledili. Posebej izstopa njegov prvi slovenski spis Vinske trte hvala.

Še bi lahko naštevali in se sprehajali od naroda do naroda. Vsak narod ima svoje buditelje. Ko preučimo njihovo pot in delo, spoznamo, da so različni, a imajo tudi skupne lastnosti. To je posedovanje nekega posebnega poklicnega in strokovnega znanja, ki močno prekaša znanje njihovega okolja. V svojem poklicnem svetu navezujejo številne dragocene stike, svoje poklicno delo pa nadgradijo $\mathrm{z}$ delom za prebivalce. Vsi se nenehno učijo in želijo, da bi se učili in aktivirali tudi drugi. Mnogi začnejo delovati politično, pogosto skupaj s prebivalci. 
Nemalokrat so moteči za obstoječe družbene ustanove, saj so znanilci in nosilci sprememb. Ko njihova »podjetja« zaživijo, jih nemalokrat prepustijo v upravljanje ljudem. Sebe ne postavljajo v ospredje, ali bolje rečeno, zaslug ne pripisujejo sebi, temveč ljudem. Našteto velja tudi za nekatere sodobne vidne sociokulturne animatorje. Sicer pa animacija od animatorjev zahteva učenje, znanje in tudi posebne darove. Velikokrat so v mladosti izkusili nepravičnost, zato se strastno bojujejo za družbeno pravičnost do vseh.

\section{SOCIOKULTURNA ANIMACIJA IE IZRAZ RAZLIČNIH KULTUR}

Ko govorimo o kulturi, imamo v mislih najširši pomen tega pojma, ki vključuje način življenja pa tudi izobraževanje. Kultura je zmeraj povezana z družbenim. Francoska kultura, denimo, se je oblikovala od antičnih časov sem tudi pod vplivom različnih revolucij; politične in strukturne revolucije leta 1789, znanstvene in tehniške revolucije v 18. in 19. stoletju, ki jim sledi še kulturna revolucija v 20. stoletju. To vse preplete družbeno in kulturno, pri čemer so na proces prepletanja vplivale ekonomske potrebe in institucije, kot sta javna šola in izobraževanje, pa tudi družbena gibanja, denimo socializem. Tako je zlagoma nastala nova kultura, ta pa se močno razlikuje od »tradicionalne«, kjer je šlo predvsem za estetiko, okleščeno na umetnost in književnost. Tradicionalna kultura pa se ni mogla prenoviti drugače, kot da se je integrirala $\mathrm{v}$ novo kulturo.

Kultura je družbeni konstrukt in kulture ni mogoče razumeti, če ne poznamo družbe in družbenih okoliščin, sredi katerih je nastala. Še več, kultura ima pomembno vlogo; daje vpogled $v$ dinamične družbene sile, omogoča analizo teh sil in jih strne, pri tem pa omogoča spreminjanje tradicionalnih oblik izraza, ravnanja, norm in načinov.
Kultura je družbeni konstrukt in družbeni proizvod, toda konstrukt in proizvod katere družbe, se sprašujemo. Družbe navadno poimenujemo po prevladujoči vrsti proizvodnje: predindustrijska, industrijska, postindustrijska, kar vpliva na vrsto odnosov, ki se tkejo znotraj nje. Nastop nove družbe je mogoč le ob presekanju vezi s predhodno. Industrijska družba nastane, ko preseka vezi s kmetijsko, informacijska, ko preseka vezi $\mathrm{z}$ industrijsko, itd. Spremembam in novi kulturi se prilagajamo. Kultura pa nemalokrat doživi
Sociokulturna oblika socializacije kulture. animacija je preobrazbo, kakor doživijo preobrazbo družba, človeštvo, civilizacija. Neki francoski minister je nekoč izjavil, da bodo prihodnja stoletja stoletja religije ali pa teh stoletij ne bo. Stoletja religije kulture vsekakor! Današnja, še bolj pa prihodnja družba bo temeljila na kulturi. (Besnard, 1990). Sociokulturna animacija je tako oblika socializacije kulture. Način širjenja visoke, elitne, uradne kulture in hkrati način uveljavljanja ljudske kulture, aspiracij in zmožnosti različnih družbenih slojev.

\section{RAZVOJ KONCEPTA SKOZI ZGODOVINO}

Na prvi pogled se zdi, da je francoska sociokulturna animacija nov koncept, ki se je razvil v zadnjih 30 letih kot protiutež tehnicističnemu, razosebljenemu razvoju, hitri urbanizaciji, množičnosti vsegà v industrijski družbi. Vendar gre pravzaprav za nadaljevanje dosti starejšega organiziranega ljudskega izobraževa$n j a$, ki poteka že v času francoske revolucije, ko si delavci želijo pridobiti kulturo. Ta naj bi dajala družbeno moč, tako kot jo je dajala vladajočemu razredu meščanov. Kaj kmalu ugotovijo, da jim meščanska kultura ni blizu, in tako dajo prostor svoji lastni, delavski kulturi. Poleg tega v pravnih delavskih krožkih delavci začnejo pridobivati pravno znanje, ki naj bi jim pomagalo utrditi njihov družbeni položaj. 
Vse do leta 1945 je govor o ljudskem izobraževanju, a zlagoma to izobraževanje ni več ljudsko in vse bolj se takrat govori o sociokulturni animaciji. Ta premik razkriva nekatera družbena dejstva: poudarjanje kulture $\mathrm{v}$ razvoju družbe in to, da izobraževanje ni namenjeno samo manj ukemu ljudstvu, marveč vsem družbenim razredom, tudi meščanstvu. Gre za izpopolnjevanje posameznikov in družbenih skupin, na podlagi katerega se izpopolnuje človeštvo. Izraza sociokulturna animacija in sociokulturni animator je tako mogoče srečati v nekaterih besedilih, ki govorijo o izpopolnjevanju človeštva, in sicer vse od leta 1947 dalje (kino klubi, kulturna vas itd), pri čemer animacija pomeni latinsko »vdihniti življenje«.

Sociokulturna animacija se pojavi, lahko bi rekli, tudi pod vplivom obšolskih dejavnosti v 19. in 20. stoletju. Kot pravi Raymond Labourie, tudi to vpliva na pojav sociokulturne animacije (Labourie, 1972: 16). Tako to ni nov pojav, ki bi lebdel v zraku, brez korenin ali teoretičnih

Kultura poveže narod in ga drži skupaj. temeljev. Teoretične temelje je iskati $\mathrm{v}$ razpravah o izobraževanju odraslih pri Talleyrandu (Caceres, 1964) in seveda pri Nicolasu de Condorcetu.

Nicolas de Condorcet, utemeljitelj francoske republikanske šole, je bil prepričan, da mora vsakdo imeti toliko intelektualnega orožja, kolikor ga le lahko nosi, in se je v vsem svojem delovanju bojeval za družbeno pravičnost, enakost, svobodo, razum in kulturo vseh ljudi. Napisal je monumentalno delo Načrt za javni uk, kjer v tretjem delu razlaga, kako naj bi potekalo izobraževanje odraslih. Te naj bi poučevali nedeljski učitelji v nedeljskih šolah, ki bi bile nekakšna vzporednica uradni šoli, pa tudi njena nasprotnica. $\mathrm{V}$ teh šolah naj bi dali prostor drugačnosti kultur. Odrasle pa bi bilo mogoče poučevati tudi s povečano naklado enciklopedije, v galerijah, knjižnicah, muzejih, ob pomoči poljudnih knjig, almanahov, časopisov. Njegovo prepričanje, da se morajo izobraževati vsi (celo ženske!), ustreza temeljnim načelom francoske revolucije, idealizmu, abstraktnosti, individualizmu, hkrati pa naj bi krepilo bratsko skupnost. Izobraževanje naj bi bilo namenjeno izpopolnjevanju posameznika in človeštva, zato je treba poskrbeti, da vsakdo, predvsem pa vsaka generacija, opravi prenašalsko vlogo: da na druge prenese znanje in kulturo, saj bo samo to omogočilo napredek ljudi in človeštva. To je zelo pomembno, kajti kdor nima dovolj znanja in kulture, je zmeraj odvisen od muh in volje drugega!

Njegova humanistična stališča je kasneje mogoče najti pri različnih piscih, ki vsi verjamejo v nenehen razvoj človeka in celostno izobraževanje $\mathrm{v}$ vseh razsežnostih, vključno s telesno. Tudi Unescov program Izobraževanje za vse je utemeljen na Condorcetovih prepričanjih. Ta prepričanja pa najdemo tudi $\mathrm{v}$ sociokulturni animaciji. In prav dejstvo, da se je sociokulturna animacija v Franciji razvila konceptualno in $\mathrm{v}$ praksi ter postala podsistem kulturne politike - z različnimi nosilci na različnih ravneh in ob podpori države -, je posebnost tega koncepta in te celote praks. Kljub vsemu pa je sociokulturna animacija praktično in akcijsko naravnana, tako da več raziskav s tega področja dobimo šele po letu 1960, torej razmeroma pozno. Diskurz sociokulturne animacije pa je še vedno humanističen, idealističen in družbeno transformativen. Sociokulturno animacijo tako pogosto najdemo sredi radikalnega izobraževanja odraslih, torej izobraževanja odraslih $v$ družbenih gibanjih, ki si prizadevajo za družbene spremembe.

Sociokulturna animacija je tako še zmeraj podsistem francoske kulturne politike. Prvi francoski kulturni minister André Malraux je namreč verjel, da kultura pomaga strniti družbene sile, še posebno $\mathrm{v}$ ateističnih družbah. $\mathrm{V}$ njegovem

Kultura in znanje, ki ju širijo nosilci sociokulturne animacije, imata individualno in družbeno transformativno vlogo, zgodovinsko vlogo, vlogo prenašalcev občih vrednot, vlogo povezovalcev družbene skupnosti, vlogo borcev proti družbeni neenakosti. 
Vsak družbeni sistem je podvržen spremembam, a je tudi tako narejen, da teži k temu, da se uravnoteži. Sociokulturna animacija je odziv na družbene spremembe ali njihova znanilka, včasih jih tudi sooblikuje, včasih poskuša pripomoči k vnovičnemu vzpostavljanju družbenega ravnotežja. Zgodovinsko gledano, smo dejali, se razvije iz ljudskega izobraževanja, in sicer iz treh tokov: konfesionalnega, posvetnega in sindikalnega. Iz sindikalnega in političnega izobraževanja, izobraževanja na borzah dela (1886) se razvije tudi velika inovacija: ljudska univerza kot najvišja oblika ljudskega izobraževanja, oblika kulturnega in vzajemnega izobraževanja, ki še danes prepreda Francijo. Še nedavno je sociokulturni animator Michel Onfray, doktor filozofije, pustil delo v državnih ustanovah in ustanovil pomembno ljudsko univerzo na atlantski obali. Zavel je nov veter, nastale so nove ljudske univerze $\mathrm{z}$ novimi vsebinami za ljudske množice.

času je celo veljalo, da je treba dati kulturi prav posebno mesto, saj ima kultura vlogo kolektivnega odrešitelja; narod obvaruje pred nevarnostjo in ga trdno poveže. Kultura in umetnost $\mathrm{v}$ retoriki Andréja Malrauxa pomenita nekaj, kar ni dano samo po sebi, marveč nekaj, kar je treba pridobiti, doseči, usvojiti. Kultura in umetnost ustvarjata skupno občutljivost, gradita skupnost. Malrauxove misli so dale podlago za nastanek ministrstva za kulturo in že leta 1959 si je francoska republika postavila nalogo, da bo velike umetniške stvaritve približala čim večjemu številu ljudi (Malraux, 1996: 257). Šlo je torej za demokratizacijo kulture ne glede na siceršnji takratni družbeni model. Francoska država si je tako v 60. letih prejšnjega stoletja naložila nalogo, da bo iz kulture gradila svojo politiko, da bo na tej podlagi vzdrževala trdno povezanost naroda, usmerjala družbene spremembe in ponudila državljanom možnost poistovetenja s kulturo.

\section{RAZNOLIKOST NOSILCEV SOCIOKULTURNE ANIMACIJE}

Nosilci sociokulturne animacije so različni: vidni posamezniki, neformalne skupine, lokalne skupnosti, društva, združenja, občine, podjetja, ustanove vseh vrst, ministrstva. Tem nosilcem se pridružujejo še tako imenovane vmesne skupnosti, denimo gradbena in druga podjetja ter združenja, ki praktično omogočajo, da zrastejo skupnostni prostori, ki so temelj sociokulturnega delovanja, opravljajo pa tudi druge operativne naloge.
Že v času Malrauxa zrastejo kulturni centri, kjer program določajo prebivalci sami, zrastejo domovi mladih, klubi tisočev, zgradbe, ki omogočajo kulturni in izobraževalni, pa tudi sindikalni turizem $\mathrm{z}$ veliko kulturnih in izobraževalnih dejavnosti. Najbolj številni nosilci sociokulturne animacije pa so društva oziroma nevladne organizacije. Danes vemo, da so zmožnosti vlad, da opravijo družbene naloge, omejene. Zato mnoge med njimi opravljajo nevladne organizacije.

Nevladne organizacije spreminjajo ljudi in družbo. »Proizvod « nevladne organizacije je človek, ki si zna krepiti zdravje, je mladenič, ki se razvije v odgovornega moža, je starejši človek, ki se uči in si veča samozavest ter dejavno preživlja poznejša leta, je lokalno okolje, ki se zave svojih vrednosti in jih krepi. Društva so utemeljena na slovitem francoskem zakonu o društvih iz leta 1901, ki pravi, da gre za združbo ljudi, ki dohodek, ki ga ustvari, v celoti vrača v izvedbo programa.

$\mathrm{Z}$ vsemi temi možnostmi se torej gradi tisto najpomembnejše - »mentaliteta«. Mentaliteta, ki omogoča družbene spremembe na temelju prostovoljnega povezovanja, učenja in delovanja. Mentaliteta ljudi, ki so pripravljeni stvari vzeti v svoje roke:

\section{Svet se premika, pa vi?}

\section{TEDEN MEDNARODNE SOLIDARNOSTI}

\section{3.-21. NOVEMBER 2009}

KDO: društva, nevladne organizacije, krajevne skupnosti, izobraževalne ustanove, organizacije ljudskega izobraževanja 
TEME: dejavnosti organizacij, njihovi projekti, odnos do posameznih dežel, stvari občega pomena, kako razmišljati o mednarodni solidarnosti, kaj storiti

KAJ IN KJE: več kot 2000 oblik animacije v več kot 500 mestih

KAKO: razprave, predavanja, projekcije, skupna kosila, organizirani trgi izdelkov iz tujih držav, forumi (odnos med severom in jugom, trajnostni razvoj, dolgoživa družba, pravična trgovina, potrošništvo, turizem, hranilništvo, pravice otrok, odpis dolga revnim državam, mir, nenasilnost, spoštovanje človekovih pravic)

V sociokulturni animaciji se med seboj povežejo različni nosilci, pa tudi različni, navidez nepovezljivi sektorji: javni sektor, zasebni sektor, civilna družba. Povezujejo se soseske, mestne četrti, mesta, vasi, regije, nastaja evropska in nastaja globalna skupnost. Člani teh združb so nosilci kulture, izkušenj, znanja, so pa tudi dejavni državljani, ki z učenjem in delovanjem vplivajo na stanje občih reči.

Sociokulturna animacija so tako tudi akcije, ki jih vodijo posamezniki, ki se združijo v skupino, pri čemer sami določijo vsebino, družbene, kulturne in ekonomske cilje svojega delovanja.

Nazadnje je sociokulturna animacija tudi sektor družbenega življenja. Njeni nosilci imajo za cilj preoblikovanje stališč in medsebojnih odnosov. To dosežejo z delovanjem $\mathrm{v}$ javnih občilih ter $\mathrm{s}$ posrednimi metodami učenja in delovanja.

\section{POSKUS OPREDELITVE KONCEPTA}

Sociokulturna animacija naj bi kulturo približala vsem in $v$ vseh okoljih. Prizadeva si odpreti dostop do kulture v čim večjem delu življenja državljanov, pri čemer se trudi, da se vključi čim večje število ljudi tako kot v naslednjem primeru.

Festival Noči pisanja v Manosquu, vasi sredi Provanse, je prejšnji mesec privabil številne goste. Vseh starosti so bili. Majhni in veliki, mladi in sivolasi. Organizatorji so si želeli, da bi ljudem vrnili željo po pisanju, tistem pravem, ki nosi s seboj občutja, čustva, lepe in natančno izražene misli. Misli, katerih izraz je zmeraj drugačen, pač glede na to, komu so namenjene. Po vsej vasi so tako nastale »sobe za pisanje«. In $v$ teh sobah so se čez dan zadrževali mimoidoči, skriti pred pogledi drugih, z namenom, da napišejo pismo, kartico, daljše sporočilo ali črtico. Preprosto karkoli, kar jim je čez dan ali tisti trenutek seglo v misel. Takšne sobe je bilo tako najti na obronkih jas, tam, kjer se pogled širi navzdol, $v$ dolino oljk, kjer pihlja topel vetrc. Ali pa v vaški gostilni. Včasih so jih organizatorji skrili kar za kakšen plakat in tja na mizo postavili pisalni pribor: pero, črnilo, pivnik, radirko. »Soba za pisanje«je bil tudi improviziran razred na prostem, takšen opremljen z med seboj povezanimi šolskimi klopmi in obdan z mediteranskim rastlinjem. Tam, v tej »enajsti šoli pod oljko«, so bili predvsem otroci, ki jih je igra pisanja povsem posrkala vase. Ob večerih pa so se obiskovalci srečali s pisatelji sredi vaškega trga, ob vodnjaku, v vaški gostilni ali kar pri peku. Dolgo v noč odprta pošta je omogočila, da so obiskovalci vse do poznih nočnih ur polnili skrbno izbrane pisemske ovojnice. Nanje so pritisnili rdeče voščene pečate $z$ začetnimi črkami svojega imena. Dišavili so pisma. Poleg tega se je bilo v vasi mogoče udeležiti delavnic lepopisja, predavanj o pisavah in epistolarni umetnosti. Pa tudi delavnic ustvarjalnega pisanja ni manjkalo.

Sociokulturna animacija pomeni akcije $\mathrm{v}$ eni ali več skupinah, kolektivih ali okolju, ki težijo $\mathrm{k}$ boljšemu sporazumevanju $\mathrm{v}$ družbi in strukturiranju družbenega življenja, pri čemer uporablja poldirektivne metode. Gre za metodo družbene integracije in participacije. Naslednji primer predstavlja prizadevanja radijskega novinarja, da bi s pomočjo kulture vključil $\mathrm{v}$ družbo brezposelne in brezdomce.

Animatorji radia France Urgences, ki ga je ustanovil Emmanuel Moreau, želijo, da bi bil to predosem radio storitev, kjer bi ljudje 
dobili praktične informacije, radio za pogovor, kjer bi se zbirala pričevanja in vprašanja, radio nasvetov, ki bi jih dali izvedenci, zdravniki, pravniki, socialni delavci, pa izobraževalni radio ... In še ena pobuda: ob sobotah dopoldne lahko gredo tisti, ki so sicer deležni brezplačne hrane v restavracijah srca, brezplačno v kino. »Da bi tisti na robu družbe ostali vsaj malo sredi dogajanja ..." (iz zasebnega pisma, januar 2003)

Socioanimacija je oblika prilagajanja novim oblikam družbenega življenja, je zdravilo za neprilagojenost ter služi osebnemu in kolektivneти razvoju. To opredelitev ilustriramo $\mathrm{z}$ naslednjim primerom.

Kje je mogoče prelistati use dnevno časopisje in pri tem srkati kavo? Kje se je mogoče družiti v kavarni, ki jo vodijo dijaki? Kje je mogoče prisluhniti igralcem, ki berejo občinstvu dela Stefana Zweiga? Kje se je mogoče učiti kaligrafije, takole mimogrede, po koncu službe? Kje lahko prisostoujemo pogovoru o človekovi usodi ali kje se je mogoče vključiti v delavnico ustvarjalnega pisanja? $V$ srcu Clermont-Ferranda, $v$ ulici Sous-les Augustins, je kavarnica-bralnica, ki so jo ustanovili dijaki. Rodila se je iz zamisli 12 ljudi. Nastalo je društvo. V statutu so člani zapisali, da se bodo bojevali proti krivicam, nestrpnosti, neenakosti in kulturnemu razlikovanju. »Organizirali smo odbor in štiri leta smo si prizadevali, da bi odprli takšno kavarnico, prostor, ki bi ustrezal vsem, "je povedal Christian, eden od devetih prostovoljcev, ki upravljajo prostor in animirajo življenje v njem. Laurent je mlad, brezposelen, a se »dobro počuti, saj ga nič ne priganja, da bi moral prostor zapustiti, ko spije kavico«. $V$ tej kavarnici ni nadzora. Poleg osladnih romanov so na voljo knjige velikih klasikov, revija Esprit, nekaj takega kot slovenska revija Sodobnost, je postavljena na polico skupaj z lokalnim časopisom. (povzeto po $L^{\prime}$ Humanite Hebdo, št. 25, 7. maj 1998)

Naslednja opredelitev sociokulturne animacije je z vidika učnih metod. Socioanimacija je sku- pek učnih metod, ki temeljijo na razumevanju drugega, na delovanju in vzpostavljanju enakovrednih odnosov in odpravljanju hierarhičnih razmerij $v$ skupini. Odnosi v skupini so svobodnejši in samostojnejši. Člani skupine se sami odločajo o tem, kako bo potekalo njihovo učenje in delovanje, s katerim spreminjajo sebe in okolje. Učenje je pogosto recipročno in vzajemno. Sociokulturna animacija je razvejan pojav in tako so številne tudi njene opredelitve. Za nekatere je sociokulturna animacija predvsem: (1) metoda organizacije in zaposlitve $v$ prostem času, ki spominja na severnoameriške rekreacijske metode. $\mathrm{S}$ terciarizacijo gospodarstva pa tudi s prvo naftno krizo in institutom zgodnje upokojitve se namreč sredi industrijskega obdobja pojavi prosti čas, ob tem pa tudi prizadevanja za »zapolnitev« tega časa. Gre za prosti čas v dnevu, ob koncu tedna, za letne počitnice (Besnard, 1990: 34). Vendar prosti čas ni čas brez vsebine, marveč vse bolj čas, ki je namenjen osebnostni rasti in izobraževanju. Iščejo se nove vsebine in dejavnosti, ki imajo trden smisel in namen. Razvije se izobraževalni, kulturni, sindikalni turizem. Vse več je študijskih dni, seminarjev, kongresov, ki jih prirejajo društva, politične skupine, religiozne skupine, ustanove. Razvijejo se tudi prostočasne oblike dejavnosti za upokojence, kot so klubi upokojencev ali univerze za tretje življenjsko obdobje. Vse te in druge oblike sodijo v sociokulturno animacijo. Prosti čas pa ni le pozitiven, temveč prinese tudi negativne pojave, kot so uživanje mamil, alkoholizem, depresivnost. Zaradi prostega časa se postavlja vse več socialnih vprašanj glede neenakosti med rasami, družbenimi razredi, socialnimi okolji, generacijami, kar bi lahko privedlo do novih oblik kolektivnega sovraštva. Tako nastajajo nove prostočasne oblike sociokulturne animacije, ki pa nikakor niso zgolj rekreacija.

Po letu 1960 je vprašanje prostega časa vse bolj zanimivo tudi za komercialni sektor. Pojavi se prva »prostočasna vas«, prvič organizirajo sejme za prosti čas. Prosti čas tako ni več nekaj obrobnega, temveč se povezuje z dru- 
gimi vidiki današnje civilizacije. Na subtilen način je povezan z vsemi veliki vprašanji dela, družine, politike, saj prosti čas vpliva na delo, družino, kulturo. Š e posebno tisti prosti čas, ki ga imenujejo »resni prosti čas « v nasprotju $\mathrm{z}$ »naključnim prostim časom « brez konstruktivnih posledic za človeka ali družbo;

(2) možnost družbenega osvobajanja množic. Te naj izrazijo svojo pravo ljudsko kulturo v nasprotju z elitno ali uradno. Pomemben izraz dobijo tudi lokalne ljudske kulture in posamezne manjše družbene skupine, ki lahko pokažejo svojo značilno kulturo. Poglejmo primer:

Hoditi in pri tem ne slišati svojih korakov je nenavadna izkušnja. V takšnem stanju, kot da bi bili oviti v vato, prisostoujemo Scenam tišine, kot so poimenovali novo razstavo $v$ Mestu znanosti in industrije. Namen razstave? Narediti obiskovalce občutlivive za vsakdanje življenje gluhih in slabo slišečih. Avtor razstave Andreas je že pred desetimi leti poskušal narediti nekaj podobnega v povezavi s slepimi. In požel je aplavze. Začelo se je, ko je bil Andreas novinar na nemškem državnem radiu. Leta 1990 je poskušal pomagati oslepelemu kolegu, da se vrne na delo, in tako se je spoznal s slepimi. Ta svet ga je tako pritegnil, da je v Hamburgu ustanovil organizacijo za ponovno vključitev hendikepiranih $v$ družbo.

Razstavo lahko obišče 12 obiskovalcev hkrati. Ogled traja 50 minut in poteka v popolni tišini. Obiskovalci nosijo čelade in ne slišijo zunanjih zvokov, temveč le utrip svojega srca, slišijo ga nenavadno močno, kot da gre za grozljivo sceno. Kaj kmalu se znajdejo sredi komedije. Igralec, ki je vodnik po razstavi, poskuša obiskovalcem z mimiko, kretnjami in gibanjem predati sporočilo. Ko jih vodi od dvorane do dvorane, jih spodbuja, naj se tudi sami izrazijo z rokami in mimiko obraza. $\mathrm{Na}$ koncu obiskovalce čaka Kavarna znakov. Tu je treba pozdraviti natakarja, naročiti pijačo, se zahvaliti. Čelada s slušalkami obiskovalcem pomaga slišati mehurčke gazirane pijače tako kot v kakšni reklami. Obisk razstave ima $v$ sebi nekaj igrivega za vse, primeren je tudi za otroke od osem let dalje. (prevod in priredba po Le Monde, 22. december 2003: 17)

(3) ideologija družbene participacije, ki naj omogoči družbeni razvoj brez trenja. Vsaka družba za to potrebuje vmesne skupnosti, skupnosti med družino in državo;

(4) način spodkopavanja družbenega reda, saj se izobraževanje in širjenje kulture nemalokrat prelevita v akcijo za boljši položaj družbenih skupin;

(5) za tehnike in strokovnjake je sociokulturna animacija priložnost, da znanje in veselje prenesejo na druge, da delajo na področju kulture in uveljavijo svoje stvaritve;

(6) za borce je sociokulturna animacija možnost, da uveljavijo svoje ideale, da drugim prenesejo svoje vrednote, pa tudi strahove. Skupine in društva imajo večjo možnost izražanja in večji vpliv kot posamezniki;

(7) za kulturne tehnokrate je sociokulturna animacija deklica za vse. Vse, kar ne postori država, naj opravi sociokulturna animacija;

(8) za lokalne veljake je to možnost, da utrdijo ali pogubijo svojo vladavino;

(9) socialna okolja premostijo svoje sociokulturne težave, preprečujejo prestopništvo in druge težave našega časa. Poglejmo primer:

Cécile Ladjali je avtorica razprav o izobraževanju in predavateljica na Univerzi Sorbonne Nouvelle. Že 13 let predava $v$ različnih ustanovah $v$ francoskih predmestiih. $V$ gimnaziji Louise-Michel v Bobignyju vodi pedagoško sociokulturno akcijo, s katero poskuša dijake, ki so večinoma arabskega rodu, odvrniti od antisemitizma. Pri tej nalogi ji pomagata Sofoklej in Shakespeare. Tako mladi laže razumejo, za kaj gre v spopadih na Bližnjem vzhodu. Skozi te tragedije učenci zagledajo svoj položaj. Cécile jih pelje tudi na predstave v pravo gleališce, pa na predavanja $v$ dom kulture. Književnost mladim pomaga, da začnejo razmišljati, njihovi pogovori dobijo globljo in širšo kulturno razsežnost torej. (različni ustni in pisni viri)

(10) način, da s pomočjo kulture strnemo posameznike in družbene skupine ter spodbudimo 
razvoj gospodarstva (ateljeji za usposabljanje funkcionalno nepismenih, zadruge psihiatričnih bolnikov, zadruge za ponovno vključevanje ločenih žensk v poklicno življenje);

(11) kritika sodobne družbe oziroma način, kako s kulturo vplivati na družbeni razvoj.

\section{TIPOLOGIJA SOCIOKULTURNE ANIMACIJE NI MOGOČA}

Ker je sociokulturna animacija izjemno razvejan pojav, se zdi, da tipologije sociokulturne animacije ni mogoče postaviti. Nasprotno pa lahko izluščimo prevladujoče kriterije za posamezne oblike. Glede na posamezne izbrane kriterije govorimo o: (1) animaciji v mestu ali na deželi (zemljepisni kriterij), (2) družbeni in kulturni animaciji (raven), (3) politični, trgovinski, šolski, umetnostni animaciji (glavni sektor), (4) poklicni nasproti prostovoljni animaciji (status udeleženih), (6) javni in zasebni animaciji (ustanove), (7) pridobitni in nepridobitni animaciji (cilji), (8) animaciji, osredotočeni na vsebino ali na skupino, (9) animaciji, osredotočeni na učenje ali odnose in sporazumevanje v skupini (pedagoški kriterij).

Še več, ti kriteriji se lahko prepletejo. Lahko pa uporabimo tudi dodatne kriterije, kot so: (10) starost (animacija mladih, starih), (11) poklicna kategorija (animacija pedagoških delavcev, društvo inženirjev gradbeništva, animacija delavcev, kmetov, uslužbencev), (12) spol (moški, ženska), (13) vsebina dejavnosti (animacija glasbenih prostočasnih dejavnosti, turistična animacija, gledališka animacija, foto klub, filmski klub), (14) značilnosti ciljne skupine (intelektualci, aranžerji ...), (15) ustanova, kjer animacija poteka (muzejska animacija), (16) stroški (finančni kriterij).

Iz vsega povedanega sledi, da obstajajo neki skupni elementi: dogajanje $\mathrm{v}$ kolektivu ali skupini, pomen družbenega sporazumevanja, izboljševanje družbenega sporazumevanja s pomočjo animatorja. Pri tem se uporabljajo učne metode, ki so aktivne in nedirektivne, kar zahteva avtonomnost in odgovornost vpletenih. Sociokulturna animacija se dogaja v skupnosti, na temelju družbenih odnosov in zaupanja, veča socialni kapital, kar ima družbene, pa tudi ekonomske učinke.

\section{FUNKCIJE SOCIOKULTURNE ANIMACIJE}

Sociokulturna animacija pomeni navduševanje, povezovanje in skupno delovanje ljudi za boljše življenje $v$ skupnosti. V tej skupnosti, v tej družbi, sociokulturna animacija opravlja različne funkcije, ali bolje, opravlja veliko različnih funkcij hkrati. To je razumljivo, saj je področje njenega delovanja življenje samo $\mathrm{v}$ vseh njegovih razsežnostih.

(1) Prilagajanje, integracija $v$ družbo. Тa funkcija je še posebno pomembna takrat, ko je družba pod vplivom kriz ali družbenih prekinitev vržena iz tira. Takrat se namreč spremenijo razmerja $v$ družbi in nekateri se znajdejo na njenem robu, nemalokrat s hudimi posledicami. Velika družbena prekinitev je denimo vojna, ki povzroči migracije, pa tudi potrebo po različnih oblikah sociokulturne animacije pri priseljencih in domačinih, da sprejmejo kulturo drug drugega. Tako so se v neki kanadski vasi domačini izobraževali, pripravljajoč se na sprejem beguncev s Kosova. Spoznavali so njihovo zgodovino, religijo, družbeni razvoj; (2) izobraževalna funkcija. To funkcijo skupaj s funkcijo ozaveščanja denimo opravljajo različne oblike sociokulturne animacije, kot sta Noč znanstvenikov in Festival ptičev in narave v Kamargi ob ustju Rone, kjer so se združila društva in vasi v regiji. Namen festivala je poglobiti vedenje o naravi na temelju predavanj, filmskih projekcij, razstav risarjev in kiparjev živali, ob navzočnosti lovcev, ribičev in strokovnjakov;

(3) popravljalna funkcija. Rezultat družbenih gibanj, industrializacije, koncentracije delovne sile, hitre urbanizacije, demografskih premikov in uveljavitve vseobsežnih mednarodnih medi- 
jev v industrijskem obdobju je množičnost in s tem izguba identitete. Kot posledica se kažeta neprilagojenost in prestopništvo. Sociokulturno animacijo je mogoče uporabiti kot obliko aktivnega sodelovanja $\mathrm{v}$ kulturi, kot obliko vzpostavljanja vezi v majhnih skupinah, prostovoljskih društvih, kot obliko prilagajanja, kot protiutež družbenim patologijam;

(4) kritična funkcija. Med seboj se srečujejo ljudje iz različnih družbenih okolij, se učijo in poskušajo delovati za izboljšanje, denimo urbanizacije, življenja v mestu, življenja posameznih družbenih skupin, prizadevajo si za ohranitev javnega zdravstva, enakopravnost žensk, starejših ipd.;

(5) kulturna funkcija. Nekatere oblike sociokulturne animacije imajo prevladujočo funkcijo odkrivanja, razkrivanja in širjenja kulture v najširšem pomenu besede, ob tem pa povezovanja ljudi. To funkcijo dobro opravljajo različna kulturna društva pa tudi številni povezovalni kulturni dogodki, praznovanja itd., ki jih prirejajo javne ustanove, kot je denimo Noč muzejev, ki se je ob pomoči Evropske unije razširila po vsej Evropi;

(6) ekonomska funkcija. Nekoč sociokulturna animacija ni bila namenjena pridobivanju poklicnega znanja, temveč bolj pridobivanju kulture in znanja za življenje $\mathrm{v}$ skupnosti. Toda kultura lahko pomembno vpliva tudi na ustvarjanje delovnih mest in doseganje ekonomskih učinkov, kar je še posebno vidno $\mathrm{v} t$. i. vzajemnostni ekonomiji in njenih oblikah.

To so zgolj nekatere vidnejše in pogostnejše funkcije sociokulturne animacije. Podrobnejša analiza posameznih oblik lahko pokaže tudi številne druge funkcije in namene.

\section{ZAKLJUČEK}

Sociokulturna animacija, kot že ime pove, pomeni vdihniti življenje družbi s pomočjo kulture, pri čemer velja kulturo obravnavati tako, da zaobjame tudi izobraževanje. Kulturo je treba približati čim večjemu številu ljudi in ne le zgolj »ljudstvu« tako kot nekoč, s pomočjo različnih oblik sociokulturne animacije, kjer se poveže družbeno in kulturno.

\section{LITERATURA IN VIRI}

Anon (1985). Izobraževanje starejših v Franciji. Poročilo za četrto mednarodno konferenco o izobraževanju odraslih. Ljubljana: Univerza za tretje življenjsko obdobje.

Besnard, P. (1980). L'animation socio-culturelle. Pariz: PUF.

Besnard, P. (1990). El animador sociocultural; funciones, formación, profesión. Valencia: Grup Dissabte de la Federation de Animación y Cultura Popular, Conde Altea.

Cacres, B. ( 1960). Histoire de l'éducation populaire, Pariz: Seuil.

Čornaničova, R., Juraj Fándly in Samuel Tešedik (1998). »Influential Slovak Adult Educationalists of the 18th Centrury«. V Marta Friedenthal Haasse (ur.), Biography in the History of Adult Education. Frankfurt: Peter Lang, 727-739.

Dumazedier, J. (1990). La révolution culturelle du temps libre 1968/1988. Pariz: éd. Méridiens Klimcksiecck.

Findeisen, D. (1998). »O kulturi in izobraževanju odraslih. Usposobljenost za kulturo«. Andragoška spoznanja, 1-2: 4-7.

Findeisen, D. (2001). »Univerza za tretje življenjsko obdobje in kulturni turizem «. Argo, 2: 182-186.

Findeisen, D. (1995). »Condorcetov prispevek k razmišljanju o vlogi učenja $\mathrm{v}$ človekovem in družbenem življenju «. Andragoška spoznanja, 3-4: 33-38.

Findeisen, D. (2000). »Lindemanovi filozofski temelji andragogike«. Andragoška spoznanja, 6: 74-82.

Findeisen, D. (2005). »Recipročnost učenja odnosov V študijskih krožkih in drugih učnih skupinah «. V Nevenka Bogataj (ur.), Študijski krožki od zamisli in sadov v prvem desetletju. Ljubljana: ACS.

Friedel-Siegelhuber, B., Georg Wieninger (18591925) (1988). »Ein Pionier des ländlichen Erwachsenenbildung «. V Marta Friedenthal Haasse (ur.), Biography in the History of Adult Education. Frankfurt: Peter Lang. str. 559.

Henderson, P. Thomas, D. N. (1994). Skills in Neigbourhood work, London, New York: Routledge.

Juhant, J. (1989). Krekovo berilo. Celje: Mohorjeva družba. 
Kintzler, C. (1984). L'instruction publique et la naissance du citoyen. Pariz: Minerve.

Krajnc, A. (ur.) (1992). Kako smo snovali slovensko univerzo za tretje življenjsko obdobje. Ljubljana: UTŽO.

Kump, S. (2004). »Radikalno izobraževanje odraslih. Integralni del procesa družbenih sprememb«. Andragoška spoznanja.

Labourie, R. (1972). De quelques problémes de l'animation et de la formation des animateurs. Cahiers de l'animation, 1.

Mijoč, N. Krajnc, A., Findeisen, D. (1992). Študijski krožki. Ljubljana: ACS.

Ziegler, C. (1998). »Outstanding Women in Adult Education: The Exceptional Landascape of the British and the American Zones in Occupied Germany « (1945-19949). V Marta Friedenthal Haasse (ur.), Biography in the History of Adult Education. Frankfurt: Peter Lang, 642-643). 